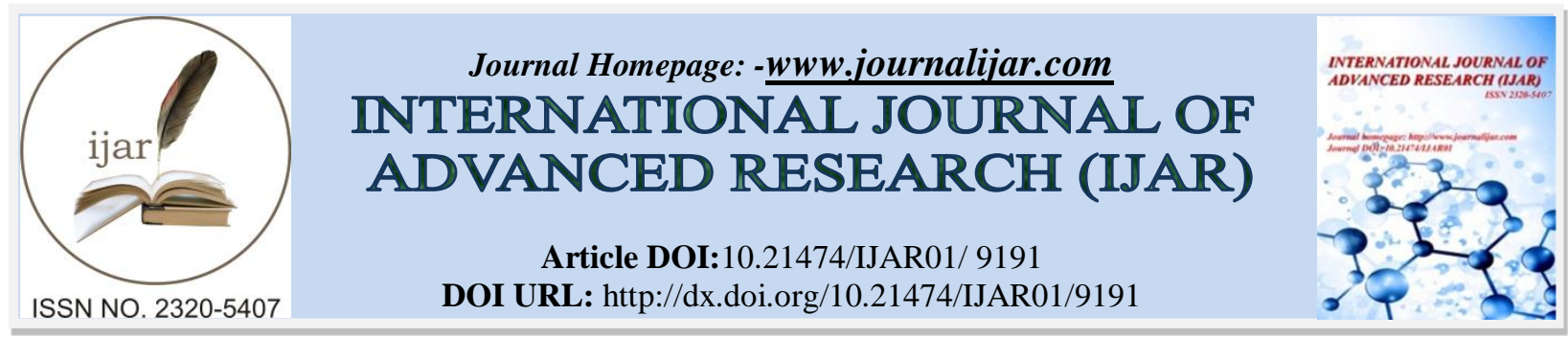

RESEARCH ARTICLE

\title{
THE DEVELOPMENT OF TRAINING MODEL IN IMPROVING ISLAMIC INTELLIGENCE BASED ADVERSITY FOR NEW STUDENTS.
}

\section{Hidayat Ma'ruf ${ }^{1}$, Sokip $^{2}$ and Akhyak ${ }^{3}$.}

1. Associate Professor, Antasari State Islamic University, Banjarmasin, South Kalimantan, Indonesia

2. Associate Professor, State Islamic Istitute of Tulungagung, East Java, Indonesia.

3. Professor, State Islamic Istitute of Tulungagung, East Java, Indonesia.

\section{Manuscript Info}

\section{Manuscript History}

Received: 02 April 2019

Final Accepted: 04 May 2019

Published: June 2019

Key words:-

Adversity Intelligence,

Islamic Value Integration,

Training Model

\begin{abstract}
Everyone has different abilities dealing with problems. Intelligence in facing difficulties and the ability to survive in various difficulties of life is called as Adversity Quotient (AQ) popularized by Paul G. Stoltz. People with high AQ do not give up easily and have high fighting power in realizing their dreams, so they are generally successful. Conversely, those with low AQ are easy to give up then they are vulnerable to failing to achieve their goals. This study tries to develop a training model to improve AQ that is integrated with Islamic values. Integration of Islamic values becomes important considering the research subjects are students of the State Islamic University with the consideration that the belief system (Islam) greatly influences all aspects of their lives. This research uses Research and Development design by Borg and Gall which is simplified into 5 stages, namely: 1) Preliminary study and needs analysis, 2) Initial product development, 3) Expert Validation, 4) Small group trials, and 5) Limited group trials. The results of the evaluation and testing of the training model developed proved to be able to improve the adversity intelligence of the new students, so it can be concluded that the training model developed based on Islamic values is appropriate, feasible, and effective to improve the adversity intelligence of students.
\end{abstract}

Copy Right, IJAR, 2019,. All rights reserved.

\section{Introduction:-}

In this world no one lives without problems, life is always side by side with various problems, as long as people live and expect something in this world, so long as it is also he will face problems. The problem is something that must be solved or solved. Humans have different attitudes in dealing with a problem. There are people who respond to a problem positively, he views the existence of a problem as something that is natural, even consider the problem as a means to train themselves in the process of achieving success, the problem that is being faced is considered a challenge to practice life towards a better life. But others respond negatively to problems, problems are seen as a very burdensome obstacle, when problems come, they complain and there is less effort to overcome them. Generally those who view the problem negatively have a weak fighting mentality and often fail to achieve their goals. 
In this world no one lives without problems, life is always side by side with various problems, as long as people live and expect something in this world, so long as it is also he will face problems. The problem is something that must be solved or solved. Humans have different attitudes in dealing with a problem. There are people who respond to a problem positively, he views the existence of a problem as something that is natural, even consider the problem as a means to train themselves in the process of achieving success, the problem that is being faced is considered a challenge to practice life towards a better life. But others respond negatively to problems, problems are seen as a very burdensome obstacle, when problems come, they complain and there is less effort to overcome them. Generally those who view the problem negatively have a weak fighting mentality and often fail to achieve their goals.

In Western psychology, a person's ability to deal with a problem is known as Adversity Quotient. The term Adversity Quotient was first popularized by Paul G. Stoltz in his book: Adversity Quotient: Turning Obstacles into Opportunities (1997), Stoltz, in Okka Rhys, defines Adversity Intelligence as follows: "The intelligence in his face difficulties or obstacles and the ability to survive in a variety of life's difficulties and challenges experienced". 1

Intelligence Adversity is a factor that determines a person's ability to succeed. Someone who has high adversity intelligence is able to change or process the problem that is being faced is a challenge that must be resolved so that it does not hinder the ideals he wants to achieve. In other words, someone who has high Adversity Intelligence will be better able to realize his ideals than people with low Adversity Intelligence.

Furthermore Stoltz explained that the high and low Adversity Intelligence is a predictor of things as follows: 1) How resilient someone is in facing a problem; 2) Success or failure of someone over the obstacle; 3) Who can achieve the expected performance and who will fail; and 4). Who is desperate and who will survive.

Stoltz likens humans who face problems in their lives as someone who is traveling (climbing) to the top of a mountain. Stoltz divides climbers into 3 types, namely:1) Quitters, 2) Campers and 3) Climbers. Each type has its own traits. ${ }^{2}$

Quitters have characteristics such as easy surrender and easy despair. They are not quick to accept big opportunities or tend to reject them. Challenges are something that is not liked and this type is very difficult to build relationships so that few have friends. They are difficult to adapt to a change. This type can be recognized by the use of words like "don't want to," "impossible," and so on. Quitters have a life that tends to be flat and unpleasant. They do not have a goal (vision) for the future so for them life is just as simple.

Campers are the type of people who have a number of initiatives, a little passion for life, and only show some effort. When they have reached a stage, this type of person will usually feel satisfied quickly. Change is something that makes them feel uncomfortable so they tend to feel at home with the conditions. The words liked in the form of "this is already good enough", or "suffice here only", and so on. Campers do not have great achievements in their lives because they want to try but tend to stop at certain posts or not finish. They often sacrifice their individual abilities to get satisfaction. They are people who take into account the risks that will be taken so often take jobs that are considered safe.

Climbers are the type of person who is brave in taking risks and completing work. They love challenges and have a big spirit of life. Climbers have a high level of self motivation and always try to achieve what is best for them. This type of adaptation ability is fairly good because it is very easy to accept changes. They are potential explorers who are able to understand and accept risks and criticism. Based on these attitudes, they usually have a large contribution because they are able to maximize their potential. This type can survive in various difficult situations.

Talking about humans and problems, students, especially new students, are those who are very likely to be faced with many problems. The many problems they face are caused by various things, including the development of age. Students, in the perspective of Developmental Psychology are classified as adolescents, namely the age that is dubbed the storm and stress period due to turmoil and pressure. The transition period from childhood to early

${ }^{1}$ Okka Rhys. "Understanding IQ, EQ, SQ, AQ, AND ESQ", (2014), https://scienceandeducation. quora.com/*Understanding-IQ-EQ-SQ-AQ-AND-SQ, accessed on 20 July 2018.

2 Paul G. Stoltz, Adversity Quotient: Turning Obstacles into Opportunities, translated by Thermaya entitled Adversity Quotient: Mengubah Hambatan Menjadi Peluang, (Jakarta: Grasindo, 2004), 18. 
adulthood is experienced at the age of around 10-12 years and ends at the age of 18 to 22 years. ${ }^{3}$ At this time they experienced various kinds of psychiatric problems in their search for identity, especially if they were far away from their families. Furthermore, Hernawati in her research on new students of IPB concluded that the problems often faced by new students include; a) difficulty adapting to new friends in the room, b) difficulty understanding lecture material, c) health problems, d) homesick problems, and d) financial problems. ${ }^{4}$

Previous research regarding adversity intelligence in the scope of education has been considerable. There are survey studies such as those in high school children by Theresia Aprilia Rahmawati ${ }^{5}$, adversity intelligence in single female parents by Pranandari ${ }^{6}$, the influence of adversity intelligence on academic achievement by Matore, Khairani, \& Razak $^{7}$, the relationship between empathy, friendship, and smart adversity by Fauziah $^{8}$, adversity intelligence in older people with autistic children by Andiani \& Fauziah ${ }^{9}$, and the relationship between adversity intelligence and achievement motivation by Farelin \& Kustanti. ${ }^{10}$ All of these studies have a common thread, namely the intelligence of adversity has a positive impact on the ability of individuals to overcome their various problems, as well as the achievements they have.

Seeing this positive impact, efforts to work on a training model that can improve student adversity intelligence are important. Moreover, there are no previous studies that have examined in depth about the development of models like this. New students are considered an important subject considering the possibility of many problems faced by them, so that the ability to make peace with these problems is a must so that the ideals that are the goals of each student can be realized. The question is: How can students have high Adversity Intelligence? Having high intelligence Adversity is not impossible, but it needs a good understanding of the nature of a problem, how to react, and so on need to train yourself so that it is not easy to give up when dealing with problems and try to find solutions to overcome these problems.

As explained above, the concept of Adversity Intelligence as defense ability when faced with difficulties and the ability to overcome new students is a Western world concept popularized by Stoltz. The concept that was built and developed in Western culture is very likely that the mode of thought is filled with the values of life of Western society which are partly different from the values of Islamic's teaching, therefore considerations are needed in understanding and using it. On the other hand, every religious community, especially people who have a strong religious nature, their perceptions and conception of their lives are strongly influenced by their belief systems and religious teachings ${ }^{11}$. Because a person's belief systems can influence all aspects of a person's life's development and interaction, then an activity such as training to change attitudes and improve one's motivation is very important considering how the person's views, attitudes and religious attitudes are important.

As a student of the Islamic State University who incidentally adheres to Islam, and on the consideration that the perceptions and conception of life of religious people are strongly influenced by religious values, training to

${ }^{3}$ J. W, Santrock,. LifeSpan development. Perkembangan Masa Hidup. $5^{\text {th }}$ ed. (Jakarta: Erlangga, 2006).

${ }^{4}$ Neti Hernawati, Tingkat Stres dan Strategi Koping Menghadapi Stres pada Mahasiswa Tingkat Persiapan Bersama tahun Akademik 2005/2006. J.11. Pert.lndon. Vol. 11 No.2 (2006), 48.

5 Theresia Aprilia Rahmawati, Studi Deskriptif Mengenai Adversity Quotient pada Siswa SMA Kelas XI, (Yogyakarta: Fakultas Psikologi Universitas Sanata Dharma, 2007).

${ }^{6}$ K. Pranandari, K., Kecerdasan Adversitas Ditinjau dari Pengatasan Masalah Berbasis Permasalahan dan Emosi pada Orangtua Tunggal Wanita. Jurnal Psikologi. Vol. 1, No. 2 (2008), 121-128.

${ }^{7}$ Matore, M.E.E.M., Khairani, A.Z., \& Razak, N.A., The Influence of adversity quotient on the Academic Achievement among Malaysian Polytechnic Students. International Education Studies, Vol. 8, No. 6 (2015), 69-74.

${ }^{8}$ Fauziah, N., Empati, Persahabatan, dam Kecerdasan Adversitas pada Mahasiswa yang sedang Skripsi. Jurnal Psikologi Undip, April 2014, Vol. 13, No. 1 (2014), 78-92.

${ }^{9}$ Andriani, A., \& Fauziah, N., Hubungan Antara Adversity Intellegence dengan Keterbukaan Diri pada Ibu yang Memiliki Anak Autisme di Kota Surakarta. Jurnal Empati, Oktober 2016, Vol. 5. No. 4 (2016), 615-622.

${ }^{10}$ Farelin, F., \& Kustanti, E.R., Hubungan antara Adeversity Intelligence dengan Motivasi Berprestasi pada Mahasiswa. Jurnal Empati, April 2017, Vol. 6 No. 2 (2017), 47-56.

${ }^{11}$ Tungshan Chou. Dissociation, Paranormal Belief, and Quality of Life in Older People: The Role of Religious Piety (Article). SAGE Open. October-December (2015). 1-12. https://journals.sagepub. com/ doi/pdf/10.1177/2158244015621347, accessed on 20 July 2018. 
improve Adversity Intelligence for new students is assumed to be more effective if the material and stages of implementation are based on the values of Islamic teachings.

In connection with the need for understanding and training to improve Adversity Intelligence of students, especially new students, and in connection with the absence of the intended training model based on Islamic teaching values, and systematically arranged so that it can be used effectively, the Researchers try to develop research to produce a training product, with the research title: Development of Islamic-Based Adversity Intelligence Enhancing Training Model for New Students. This research was conducted at new students at the Antasari State Islamic University in Banjarmasin in 2018.

\section{Research Methods:-}

Research method used in this research is R \& D (Research and Development). Borg and Gall state: "educational research and development (R \& D) is a process used to develop and validate educational production" 12 . The research procedure uses the Borg \& Gall model with a simpler form, namely:

1. Conduct preliminary research (pre-survey) and analyze the product to be developed

2. Develop the initial product

3. Expert validation and revision I

4. Small group trials and revision II

5. Limited field trials and final revisions. ${ }^{13}$

The data collection is done through qualitative and quantitative ways. The instrument of data collection consisted of an adversity intelligence scale adapted from Theresia Aprilia Rahmawati ${ }^{14}$, expert test rating scale used to measure the accuracy of the product (accuracy), and the scale of the training model assessment by participants. In addition, interviews are also used to obtain data that is not netted through scale.

Data analysis techniques are adjusted to the data collected. All results from instruments in the form of scales will be analyzed quantitatively. Meanwhile, the results of interviews and expert oral comments will be analyzed qualitatively.

\section{Research Finding}

The results of the study are described based on sub-headings in accordance with the sequence of research procedures.

\section{Pre survey result and Need Analysis Hasil}

The pre-survey and needs analysis was carried out by spreading the Adversity Intelligence scale to new students at the Antasari State Islamic University of Banjarmasin, collecting 231 scales. Based on the Adversity Intelligence scale, the final number of scores of the 231 new students was 40,045. Although making the conclusion that the Adversity Intelligence of a group of people through average calculations is not a norm, but as a general description, if you want to draw a conclusion of the Adversity Intelligence level from a group of samples, the average can be taken as follows: $40.459: 231=173.35$.

Based on the table of categorization of Adversity Intelligence level as found in table 1, the number 173.35 is in the Medium category. Based on the categorization table, it can be concluded that the level of Adversity Intelligence of New Students of the Antasari State Islamic University of Banjarmasin is in the Medium category. Furthermore, if you want to see more details about the spread of the Adversity Intelligence level, it can be seen in the table below:

Table 1:-Distribution of New Student Adversity Intelligence Antasari Banjarmasin State Islamic University in 2018

\begin{tabular}{|l|l|l|l|l|}
\hline No. & Number & Category & F & Percentage \\
\hline 1 & $214.2-<252$ & Highest & 3 & $1.3 \%$ \\
\hline
\end{tabular}

${ }^{12}$ Borg, W.R. \& Gall, M.D, Educational Research: An Introduction, (New York: Longman, 1983), 772.

${ }^{13}$ Tim Puslitjaknov, Metode Penelitian Pengembangan (Jakarta: Pusat Penelitian Kebijakan dan Inovasi Pendidikan Badan Penelitian dan Pengembangan Departemen Pendidikan Nasional, 2008), 11.

14 Theresia Aprilia Rahmawati, Studi Deskriptif Mengenai Adversity Quotient pada Siswa SMA Kelas XI, (Yogyakarta: Fakultas Psikologi Universitas Sanata Dharma, 2007). 


\begin{tabular}{|c|c|c|c|c|}
\hline 2 & $176.4-<214.2$ & High & 104 & $45 \%$ \\
\hline 3 & $138.6-<176.4$ & Medium & 112 & $48.5 \%$ \\
\hline 4 & $100.8-<138.6$ & Low & 12 & $5.2 \%$ \\
\hline 5 & $63-<100.8$ & Lowest & 0 & $0 \%$ \\
\hline \multicolumn{3}{|c|}{ Sum } & 231 & $100 \%$ \\
\hline
\end{tabular}

Based on the description of these findings, it can be concluded that theoretically and supported by several results of research, new students who in fact also as an early teenager, the age dubbed the storm and stress due to turmoil and pressure, generally they are faced with various problems in their lives. If these problems cannot be dealt with and dealt with by new students well, then it will certainly be very disturbing in realizing their ideals. Students will be able to deal with and overcome various problems well if they have good Adversity Intelligence. Good Adversity Intelligence can be developed through training that is structured in such a way that is based on Islamic values considering that Islamic State Islamic University students and some concepts of adversity intelligence are developed through a framework of Western life values that can be contrary to the values adopted by college student. Therefore, the significance of this training is important to be held based on consideration of the results of the needs analysis in the field.

\section{Result of the First Product development}

The product training model increases the Adversity Intelligence of the new students of the Antasari State Islamic University in Banjarmasin which are developed consisting of: 1) Training Materials, and 2) Training Steps and Strategies to Improve Adversity Intelligence.

\section{The details of the two types of products are as follows: Training Material}

Broadly speaking, the training material contains: Understanding of intelligence, various forms of intelligence and its relation to success in life, adversity intelligence, dimensions of adversity intelligence, human types in dealing with problems, and steps to improve adversity intelligence. All the material presented in the training material besides being based on its original source, namely Paul G Stoltz's opinion, is also discussed from a long angle that originates from the values of Islamic teachings. This is because the training participants aimed at new students have the physical disability of Antasari which in fact is Muslim.

In summary, material Outline can be seen as follows:

1) Definition of intelligence based on Islamic perspective

2) Life intelligence and success

3) Adversity Intelligence based on Islamic perspective

a) Definition of Adversity Intelligence

b) Dimension of Adversity Intelligence

(1) Patient

(2) Recognizing Mistakes and Great Souls

(3) Optimistic

(4) Effort

4) Types of Humans When Facing Problems
a) Quitters
b) Campers
c) Climbers

5) Steps to increase Adversity Intelligence

a) Muhasabah (love)

(1) Be aware of the problem at hand

(2) Exploring the possible causes of problems

(3) Convincing oneself is able to overcome problems

b) Mujahadah (Optimistic and earnest doing something that can bring him out of trouble)

\section{Training Steps and Strategies to Improve Adversity Intelligence}

Training steps and strategies are a guide to the steps that must be carried out by an instructor when presenting material and providing training to improve Adversity Intelligence, including: What materials are delivered in order 
step by step, how long the time allocation is available for each stage / session / material presented, how the method is and what media are used.

In summary, steps and training strategies can be seen as follows:

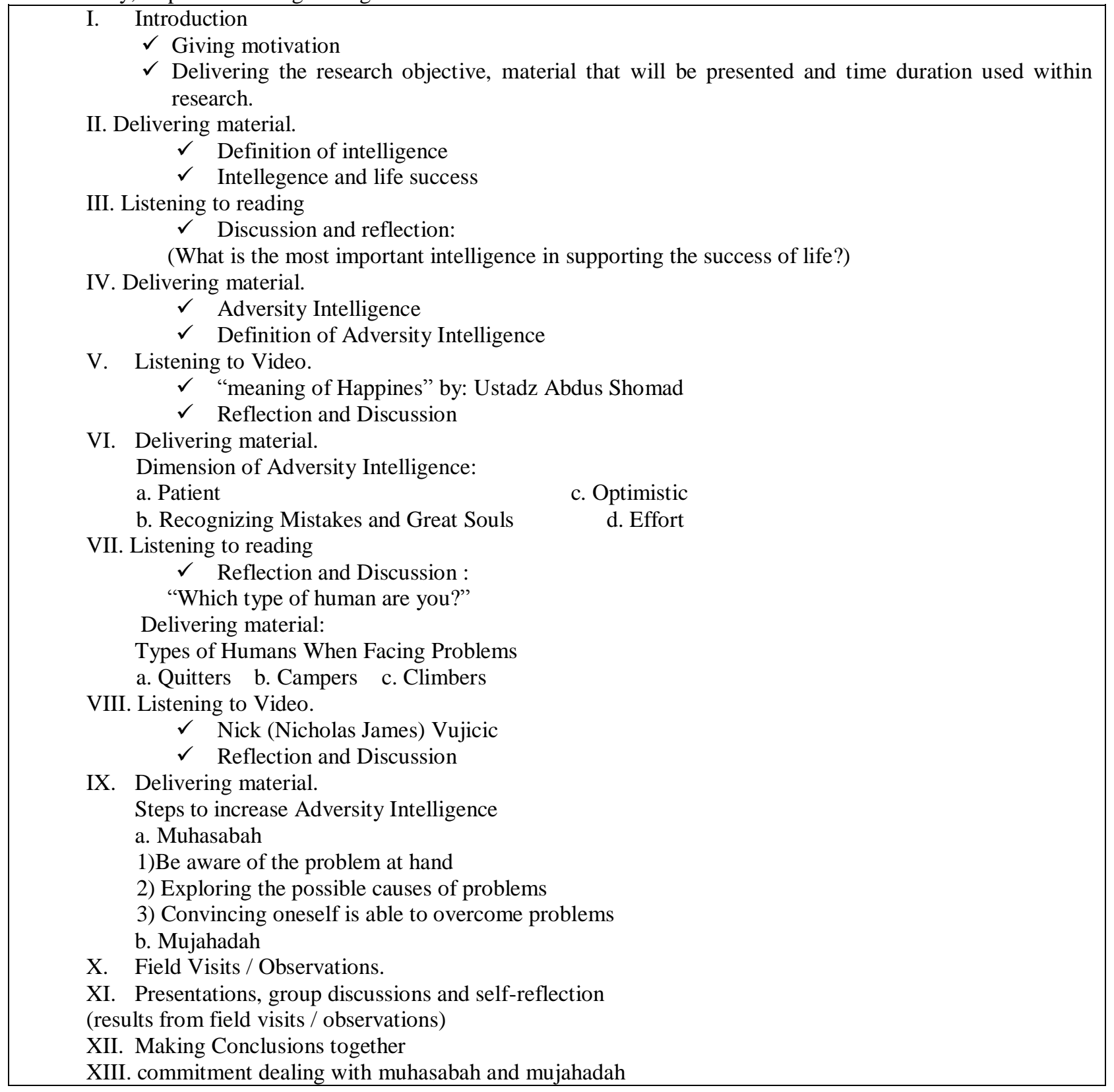

\section{Product and Revision Test Results}

Product testing and revisions are conducted three times through: 1) Product evaluation by Expert Examiners, 2) Evaluation of products by prospective instructors, and 3) Assessment of training by trainees.

In the first testing phase, the Expert assessor consisted of 2 Doctoral people who had often conducted research and provided training in the field of psychology and increased motivation, namely: 1) Chairperson of the Regional Management of Asosiasi Bimbingan dan Konseling Indonesia (ABKIN) Kalimantan Selatan, dan 2) Head of Laboratory Lambung Mangkurat University Guidance and Counseling. 
Expert Appraisers are asked to provide an assessment of product design consisting of: a) Training Materials, and b) Steps and training strategies. Assessment is given in 2 forms, namely in the form of scale and in the form of comments. In the form of a scale, the assessment uses a scale of $1-4$. The rating score is as follows: $1=$ If you strongly disagree, 2 = If you disagree, $3=$ If you agree, and $4=$ If you strongly agree.

The results of the Assessment from Expert 1 show satisfactory results with a total score of 67 or an average of 3.5 which means he agrees, some even strongly agree with the material developed. Meanwhile, the number of results of the assessment from Expert 2 is 71 or an average of 3.7 which indicates that he was largely very amenable to the design of the training material.

In addition to quantitative assessments, the two experts also gave comments which became the basis for the author in making revisions to the material. Comments and revisions are contained in Table 2.

Table 2:-Revision of Product Design from Expert Appraisers

\begin{tabular}{|l|l|l|}
\hline No & \multicolumn{1}{|c|}{ Revision Advices } & \multicolumn{1}{c|}{ Revisions made } \\
\hline 1 & $\begin{array}{l}\text { Language packaging in the training material seems } \\
\text { rather stiff. It needs to be packaged in more popular } \\
\text { languages, writing with images and concise. }\end{array}$ & $\begin{array}{l}\text { The design of the training material is repackaged by } \\
\text { including illustrations / images, using language / terms } \\
\text { that are easier to understand, interesting and match the } \\
\text { characteristics of participants. } \\
\text { Regarding language and terms, is it easy for the } \\
\text { participants to understand, concretely it will be known } \\
\text { through the rating scale and interviews when the field } \\
\text { test is limited later. }\end{array}$ \\
\hline 2 & $\begin{array}{l}\text { Training method which is done by avoiding the } \\
\text { terms of telling, showing, and doing but in order } \\
\text { using doing, showing, and telling. }\end{array}$ & $\begin{array}{l}\text { Based on the Expert Appraiser's input, each session / } \\
\text { material begins with involving participant activities } \\
\text { such as: asking questions, quizzes, modeling, role } \\
\text { playing, and reading guides, after which it is then } \\
\text { followed by explanation. }\end{array}$ \\
\hline 3 & $\begin{array}{l}\text { The material being aired is still "patronizing", less } \\
\text { challenging participants to get involved in } \\
\text { "thinking", for what is more problematic }\end{array}$ & $\begin{array}{l}\text { The material aired through the LCD sequence and } \\
\text { explanation follows as contained in the training guide. } \\
\text { The training guide was revised as suggested by Expert } \\
\text { Appraisers with Do, Show, and Tell, so it was more } \\
\text { problematic and not "patronizing" anymore. }\end{array}$ \\
\hline 4 & $\begin{array}{l}\text { The procedures for implementing the training need } \\
\text { to be detailed, preferably made per session with } \\
\text { each of them mentioned the teaching point, media, } \\
\text { time and run down. }\end{array}$ & $\begin{array}{l}\text { The procedure for implementing the training has been } \\
\text { detailed. In each session / material mentioned the } \\
\text { purpose, time, method, procedure / steps that must be } \\
\text { done. }\end{array}$ \\
\hline
\end{tabular}

After the material was revised according to expert advice, the next trial phase was in the form of a small group test, which was a trial conducted by researchers together with prospective training instructors to improve Adversity Intelligence. This trial involved 13 prospective instructors with their respective educational backgrounds, fields of expertise and professions, including: Guidance and Counseling Lecturers (as well as counselors), Psychology Lecturers (as well as Psychologists), Islamic Lecturers (as well as Ustadz).

Quantitative assessment is based on a 1-4 scale given by each prospective instructor. Decision making on the value of results on a criterion is then based on the assessment that appears most often (mode). Overall, it can be concluded that is number 3 (= agree) is the value most often given by prospective instructors, meaning that most participants have agreed to the material design, steps and strategies that will be used in training to improve Islamic-based Adversity Intelligence for new students have the physical disability of Antasari Banjarmasin.

Moreover in the examples used in the training, most participants gave a score of 4 (= strongly agree) that the instances used were very relevant to the material presented and could help clarify the material presented. Likewise with the method used, most of the participants gave an assessment of 4 (= strongly agree), meaning that the method used in the training was considered attractive. 
Nonetheless, there are some results of evaluations from participants who are still in number 2 (= disagree) on some components of the training, so it needs to be considered for revision. As for the qualitative assessment, they also provided advice that became the basis for the revision of material based on this stage. Suggestions and revisions are shown in Table 2.

Table 3:-Revision of Product Design from Participants Small Group Trial

\begin{tabular}{|c|c|c|}
\hline No & Revision Advices & Revision Made \\
\hline 1 & $\begin{array}{l}\text { Planting Islamic values can be supported by verses } \\
\text { related to adversity, with the consideration that the } \\
\text { Qur'an is the way of life. Besides that, it is also } \\
\text { supported by a piece of the story from the Prophet } \\
\text { Muhammad SAW with the consideration that the } \\
\text { Prophet's self was uswatun hasanah. Also the } \\
\text { exemplary story of Islamic figures related to } \\
\text { adversity intelligence. }\end{array}$ & $\begin{array}{l}\text { Material that is related to the dimensions of Adversity } \\
\text { Intelligence (patience, acknowledging mistakes and big } \\
\text { soul, optimistic / raja', and effort), preceded and } \\
\text { enriched with examples of stories based on the Qur'an } \\
\text { and the life story of the Prophet Muhammad SAW and } \\
\text { the exemplary stories of figures in the Islamic world. }\end{array}$ \\
\hline No & Revision Advices & Revision Made \\
\hline 2 & $\begin{array}{l}\text { Proposition (verses and hadith) related to the } \\
\text { intelligence of adversity, muhasabah and mujadalah } \\
\text { need to be added }\end{array}$ & $\begin{array}{l}\text { As a form of motivation to strengthen beliefs, verses } \\
\text { and traditions related to the virtues of prayer and } \\
\text { worship are added to the training material. }\end{array}$ \\
\hline 3 & $\begin{array}{l}\text { If possible, there needs to be a spiritual approach } \\
\text { such as that which is done or exemplified by friends } \\
\text { and Sufis. }\end{array}$ & $\begin{array}{l}\text { What the method which is still considered, can be } \\
\text { implemented as a form of enrichment or assignment for } \\
\text { participants that can be done outside the training } \\
\text { session. }\end{array}$ \\
\hline 4 & $\begin{array}{l}\text { Experiential learning method is adapted to cases } \\
\text { that are close / real with student life. Use movies / } \\
\text { videos with casts and the issues that are displayed } \\
\text { are those that are directly related to real problems } \\
\text { on campus / student life. }\end{array}$ & $\begin{array}{l}\text { Movies / videos that are aired as support for training } \\
\text { materials are sufficient enough to provide motivation to } \\
\text { trainees to not give up easily, because the difficulties } \\
\text { experienced by role models in movies / videos are far } \\
\text { more difficult than what training participants might be } \\
\text { experiencing. }\end{array}$ \\
\hline 5 & $\begin{array}{l}\text { The duration of the film / video used is too long, it } \\
\text { is feared boring, it is recommended to be shortened. }\end{array}$ & $\begin{array}{l}\text { The duration of movies / videos that are aired in less } \\
\text { than } 10 \text { minutes, does not need to be shortened again. } \\
\text { Concerns that participants are bored and lose focus } \\
\text { while watching a movie / video with duration of } 10 \\
\text { minutes (considered too long) can be dealt with by } \\
\text { assigning trainees to record the similarity of film / } \\
\text { video shows to the circumstances of each participant, } \\
\text { then participants are asked to self reflection. }\end{array}$ \\
\hline 6 & $\begin{array}{l}\text { Movies / videos that are screened need a more } \\
\text { detailed explanation regarding with adversity } \\
\text { intelligence. }\end{array}$ & $\begin{array}{l}\text { After the show is complete, the instructor and the } \\
\text { trainees will draw the conclusions with the relationship } \\
\text { of the story in the movie / video to the adversity } \\
\text { intelligence. }\end{array}$ \\
\hline 7 & $\begin{array}{l}\text { The language used in the training material should } \\
\text { be simplified so that it is easily understood by } \\
\text { trainees. }\end{array}$ & $\begin{array}{l}\text { The use of foreign or unpopular terms will be replaced } \\
\text { with terms that are easy to understand or accompanied } \\
\text { by explanations to facilitate understanding of the } \\
\text { meaning. }\end{array}$ \\
\hline 8 & $\begin{array}{l}\text { If possible, present a role model from students / } \\
\text { alumni who have physical disability as resource } \\
\text { persons / facilitators. }\end{array}$ & $\begin{array}{l}\text { Presenting alumni who have physical disability to be } \\
\text { instructors' companions during limited field trials. }\end{array}$ \\
\hline
\end{tabular}

Based on suggestions / input for improvement from the participants of the small group, either through rating scales, written comments or comments / discussions directly during and or after the completion of small group trials, several revisions have been made both in the training material and on training steps and strategies, including also involving role models from alumni of the State Islamic University of Antasari who have physical disability as an instructor companion during limited field trial training. 
After the revision is complete, the product is tested again at the limited field test stage. Limited field trials were carried out by involving as many as 26 trainees (new students), 3 instructors, and 1 (one) instructor companion as well as role models (who successfully completed Scholar or bachelor studies within 3.5 years despite limitations) physical and various other challenges).

This trial aims to gather knowledge about the training participants' assessment of the material, examples, language and methods used in the training, knowing the suitability of the time needed and other technical matters related to the training, and knowing whether there is an increase in adversity intelligence of the participants after training compared to before they attended training.

Based on the results obtained, it can be traced that the rating mode is at number 4 (= strongly agree). Especially in terms of the ease of material to be understood, the clarity of the examples used, and the attractiveness of the methods used, out of 26 training participants, there were 19-20 participants (73\% -77\%) who stated that they strongly agreed, while the rest were only 6- 7 participants (23-27\%) who agreed.

In the aspect of assessing whether the training can provide knowledge and understanding to participants to take steps in the face of difficulties, none of the participants expressed disagreement (number 2) or stated strongly disagree (number 1). Although the mode is in number 3 (= agree), but the rest is in number 4 (= strongly agree). These results indicate that the material developed meets the feasibility aspect.

Then, data related to the effectiveness of training materials in developing the intelligence of new students is obtained from the comparison of the adversity intelligence scale before and after training. Questionnaire is on the scale of adversity. Approximately two weeks before the implementation of a limited field trial was carried out, the researcher randomly distributed 100 adversity intelligence scales to new students. After the scale was reassembled and counted, the researchers randomly asked for 26 students from them ( 8 men and 18 women) to become trainees to increase the intelligence of Islamic-based adversity (limited field trials). The general description of changes toward participants' adversity intelligence before and after training sections can be seen in Table 4.

Table 4:-General Description of Participants' Adversity Intelligence Change Before and After Following Training

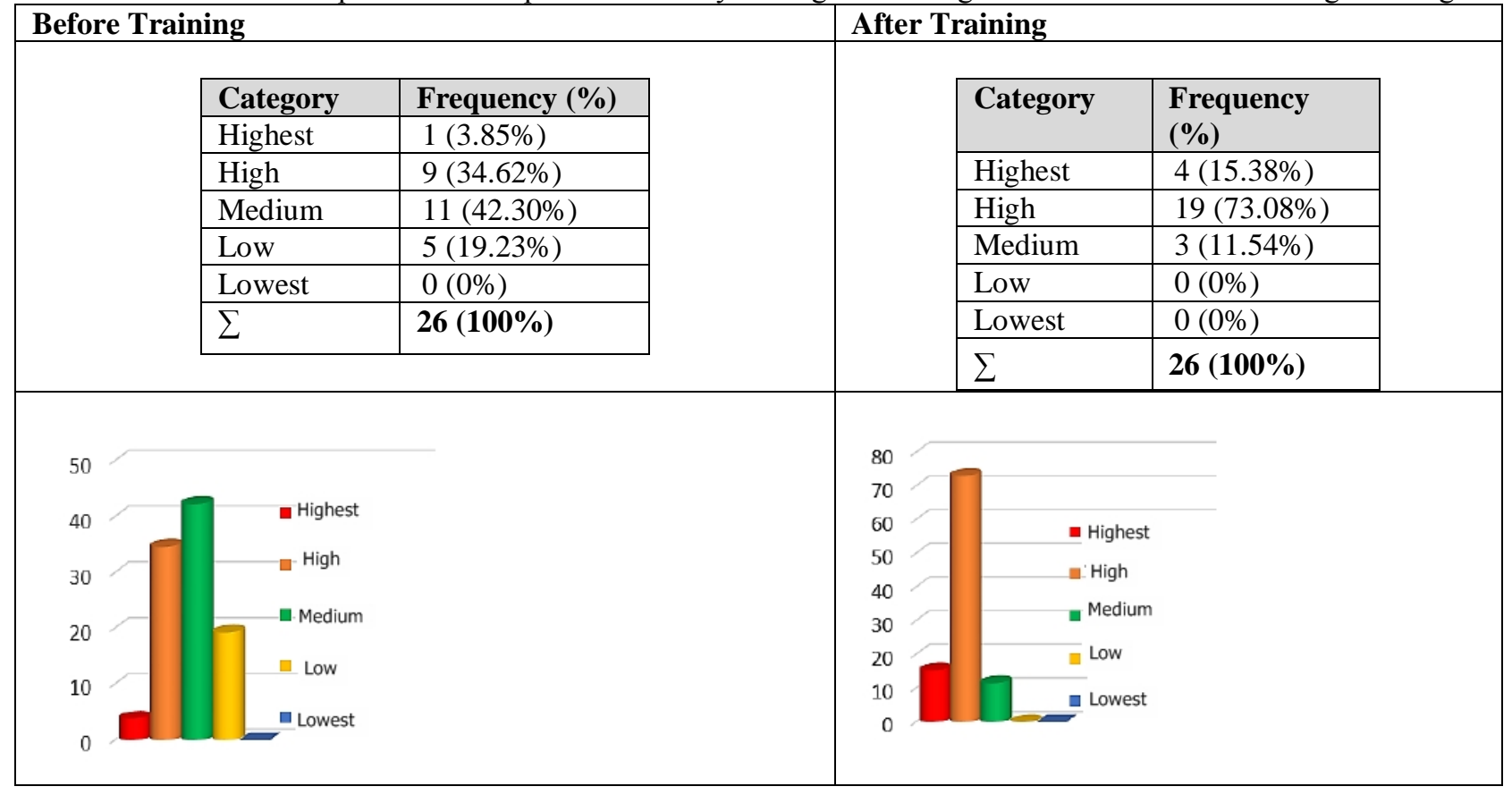

Noting the table of changes in adversity intelligence as many as 26 trainees above, both individually and in general, it can be seen that there was an increase in the adversity intelligence of the participants after they attended the training. Thus, based on the data and description above, it can be interpreted that the material, steps and strategies used in training to improve the intelligence of Islamic-based adversity, are proven to improve the adversity 
intelligence of students who take training, in other words, training models designed (both material, strategy and method) can be said to be feasible to use.

\section{Conclusion:-}

The description in this conclusion will answer the objectives set out in this study, namely: 1) Describe the level of Adversity Intelligence of new students at Antasari Banjarmasin State Islamic University, 2) Prepare Islamic-based training material that is considered feasible to improve the Adversity Intelligence of Antasari State Islamic University new students Banjarmasin, 3) Developing steps and training strategies for Adversity Intelligence, 4) Proving whether the training model developed has been used properly to improve Adversity Intelligence for new students.

1. From the scale of the assessment of adversity intelligence of new students at the State University of Antasari Banjarmasin which were randomly distributed, it was found that the adversity intelligence level was as follows: Very high (1.3\%), High (45\%), Medium (48.5\%), Low (5.2\%), and Very Low (0\%). Although the data above shows that there are some new students at the Antasari State Islamic University in Banjarmasin in 2018 the level of adversity intelligence is high, and some are even very high, but in fact most of the adversity intelligence is in the moderate category, and some are even low. That is, most of the new students at Antasari Banjarmasin State Islamic University need training to improve adversity intelligence.

2. Broadly speaking, the training material contains: Definition of intelligence, various forms of intelligence and its relation to success in life, adversity intelligence, dimensions of adversity intelligence, human types in dealing with problems, and steps to improve adversity intelligence. All the material presented in the training material besides being based on its original source, namely Paul G Stoltz's opinion, is also discussed from a long angle that originates from the values of Islamic teachings. This is because the training participants were addressed to new students at the Antasari State Islamic University who were in fact Muslim.

3. Training steps and strategies are a guide to the steps that must be done by an instructor when presenting material and providing training to improve Adversity Intelligence, including: Material that is delivered in order step by step, how long the time allocation is available for each stage / session / material presented, how the method is and what media are used.

4. Development of a Training Model for Increasing Islamic-Based Advency Intelligence for New Students This State Islamic University Antasari Banjarmasin has gone through various assessment and revision processes. Starting from the Expert's assessment and revision, followed by a trial in a small group then revised again, and finally tested again on a limited field trial by involving new students as participants. From the results of the assessment, comment, input and suggestions through the rating scale, direct and written comments, finally this model can be considered feasible. The feasibility indicator, besides being based on the expert's assessment, the assessment of prospective instructors, and the assessment of students as training participants, can also be seen from the changes or increase in the value of the adversity intelligence of the participants after they have finished training. 


\section{References:-}

1. A. Andriani, \& Fauziah, N., Hubungan Antara Adversity Intellegence dengan Keterbukaan Diri pada Ibu yang Memiliki Anak Autisme di Kota Surakarta. Jurnal Empati, Oktober 2016, Vol. 5. No. 4 (2016), 615-622.

2. Borg, W.R. \& Gall, M.D, Educational Research: An Introduction, (New York: Longman, 1983)

3. Chou, Tungshan. Dissociation, Paranormal Belief, and Quality of Life in Older People: The Role of Religious Piety (Article). SAGE Open. October-December (2015). 1-12. https://journals.sagepub. com/ doi/pdf/10.1177/2158244015621347, accessed on 20 July 2018.

4. F., Farelin, \& Kustanti, E.R., Hubungan antara Adeversity Intelligence dengan Motivasi Berprestasi pada Mahasiswa. Jurnal Empati, April 2017, Vol. 6 No. 2 (2017), 47-56.

5. Hernawati, Neti, Tingkat Stres dan Strategi Koping Menghadapi Stres pada Mahasiswa Tingkat Persiapan Bersama tahun Akademik 2005/2006. J.11. Pert.lndon. Vol. 11 No.2 (2006), 48.

6. M.E.E.M., Matore, Khairani, A.Z., \& Razak, N.A., The Influence of adversity quotient on the Academic Achievement among Malaysian Polytechnic Students. International Education Studies, Vol. 8, No. 6 (2015), 6974.

7. N., Fauziah, Empati, Persahabatan, dam Kecerdasan Adversitas pada Mahasiswa yang sedang Skripsi. Jurnal Psikologi Undip, April 2014, Vol. 13, No. 1 (2014), 78-92.

8. Pranandari, K., K., Kecerdasan Adversitas Ditinjau dari Pengatasan Masalah Berbasis Permasalahan dan Emosi pada Orangtua Tunggal Wanita. Jurnal Psikologi. Vol. 1, No. 2 (2008), 121-128.

9. Rhys, Okka. "Understanding IQ, EQ, SQ, AQ, AND ESQ", (2014), https:// scienceandeducation. quora.com/*Understanding-IQ-EQ-SQ-AQ-AND-SQ, accessed on 20 July 2018.

10. Santrock, J.W. LifeSpan development. Perkembangan Masa Hidup. $5^{\text {th }}$ ed. (Jakarta: Erlangga, 2006).

11. Shivaranjani G. Adversity Quotient: One Stop Solution To Combat Attrition Rate Of Women In Indian It Sector. International Journal of Business and Administration Research Review, Vol.1, Issue.5, April-June, 2014): 181-189

12. Shivaranjani G. and J Venkatesh. Adversity Quotient Profile: A Robust Assessment Tool to Measure Human Resilience. Asian Journal of Research in Social Sciences and Homanities. Vol. 6, No. 6, (June 2016): 412-426.

13. Stoltz, Paul G. Adversity Quotient: Turning Obstacles into Opportunities. (Canada: John Wiley \& Sons Inc., 1997)

14. Stoltz, Paul G. Adversity Quotient: Turning Obstacles into Opportunities Kecerdasan Adversitas, diterjemahkan oleh Thermaya dengan judul: Adversity Quotient: Mengubah Hambatan Menjadi Peluang, (Jakarta: Grasindo, 2004), 18.

15. Theresia Aprilia Rahmawati, Studi Deskriptif Mengenai Adversity Quotientpada Siswa SMA Kelas XI, (Yogyakarta: Fakultas Psikologi Universitas Sanata Dharma. 2007).

16. Tim Puslitjaknov, Metode Penelitian Pengembangan (Jakarta: Pusat Penelitian Kebijakan dan Inovasi Pendidikan Badan Penelitian dan Pengembangan Departemen Pendidikan Nasional, 2008), 11. 